\title{
CLINICAL FACTORS INFLUENCING ANTIPSYCHOTIC CHOICE, DOSE AND AUGMENTATION IN PATIENTS TREATED WITH LONG ACTING ANTIPSYCHOTICS
}

\author{
LIANA DEHELEAN $^{1 *}$, ANA MARIA ROMOŞAN ${ }^{1 *}$, MINODORA ANDOR $^{2 \#}$, VALENTINA \\ OANA BUDA $^{3 \#}$, ANA CRISTINA BREDICEAN ${ }^{1 \#}$, MINODORA MARINELA MANEA ${ }^{4}$, ION \\ PAPAVĂ ${ }^{1}$, RADU ŞTEFAN ROMOŞAN ${ }^{1}$
}

IDepartment of Psychiatry, “Victor Babeş” University of Medicine and Pharmacy, 2 E. Murgu Square, Timişoara, Romania
${ }^{2}$ Department of Medical Semiology II, “Victor Babeş" University of Medicine and Pharmacy, 2 E. Murgu Square, Timişoara, Romania
${ }^{3}$ Department of Pharmacology and Clinical Pharmacology, "Victor Babeş" University of Medicine and Pharmacy, 2 E. Murgu
Square, Timişoara, Romania
${ }^{4}$ Department of Psychology, "Iuliu Hațieganu” University of Medicine and Pharmacy, 8 V. Babeş Street, Cluj-Napoca, Romania

*corresponding author: ana.romosan@gmail.com

${ }^{\#}$ Authors with equal contribution.

Manuscript received: July 2019

\begin{abstract}
Treatment resistance requires higher doses and polypharmacy, thus increasing the risk of side effects and drug interactions. The objectives of the study were to identify factors predicting medication choice, dose adjustments and augmentation. The study included patients treated with long acting injectable (LAI) antipsychotics distributed into three samples: low, middle and high dosage groups (LDG/MDG/HDG). We analysed socio-demographics and clinical data (age at disorder onset, total duration of psychosis, pre-LAI and LAI treatment durations, smoking habits, adjunctive medication). Symptoms intensity was assessed with the Brief Psychiatric Rating Scale - Expanded (BPRS-E). Out of 111 patients, 31 were included in LDG, 27 in MDG and 53 in HDG. Subjects also taking mood stabilizers had higher BPRS-E scores regardless of the antipsychotic. Mood stabilizers were more frequently prescribed in HDG patients. LDG subjects presented lower BPRS-E scores than MDG and HDG patients. Subjects with mild symptoms were more frequently candidates for lower side effects of antipsychotics or lower doses of antipsychotics. Treatment resistance resulted in higher antipsychotic doses and adjunctive treatment.
\end{abstract}

\section{Rezumat}

Rezistența la tratament impune ajustarea dozelor şi polipragmazie, crescând astfel riscul efectelor secundare şi interacţiunilor medicamentoase. Obiectivele studiului au fost identificarea factorilor predictivi ai alegerii şi ajustarea dozelor. Studiul include pacienţi trataţi cu antipsihotice cu acţiune îndelungată (LAI) distribuiţi în funcţie de doza de antipsihotic în trei subloturi: doză mică, medie şi mare (LDG/MDG/HDG). Am analizat date socio-demografice şi clinice (vârsta la debutul bolii, durata totală a psihozei şi duratele tratamentului pre-LAI şi LAI, fumatul, medicaţia adjuvantă). Intensitatea simptomelor a fost măsurată cu ajutorul scalei BPRS-E. Din cei 111 pacienţi, 31 au fost incluşi în LDG, 27 în MDG şi 53 în HDG. Subiecţii trataţi cu timostabilizatoare au avut scoruri BPRS-E mai mari indiferent de tipul de antipsihotic. Timostabilizatoarele au fost mai frecvent prescrise la pacienţii HDG. Subiecţii LDG au prezentat scoruri mai mici decât cei din celelalte subloturi. Subiecţii cu simptome uşoare au fost mai frecvent candidaţi pentru medicamente cu mai puţine efecte secundare sau pentru doze mai mici de antipsihotice. Rezistenţa la tratament s-a reflectat prin doze mai mari de antipsihotic, respectiv prin augmentarea dozelor.

Keywords: long acting antipsychotics, schizophrenia, schizo-affective disorder

\section{Introduction}

The lack of insight for the disorder, stigmatization of mental illness, natural remissions with normal functioning and medication side effects are all causes of low adherence to antipsychotic treatment [9]. The duration of untreated psychosis [13] and the number of psychotic recurrences are predicting factors for the pour outcome. Partial remission of psychotic symptoms, longer durations of episodes and the need for higher attack or prevention doses reflect the onset of treatment resistance. As a result, establishing the dose of an antipsychotic considers socio-demographic factors (age, sex, race, ethnicity), as well as clinical ones (illness duration and severity, comorbid drug abuse, adjunctive medication, non-psychiatric comorbidity, body weight) [5].

The choice of the antipsychotic depends on several factors such as: its pharmacodynamic and pharmacokinetic characteristics, physician's experience with the molecule and guideline recommendations. With the exception of clozapine, it is generally accepted that the antipsychotic effect is a consequence of the 
dopamine D2 receptor blockade. Second generation (atypical) antipsychotics (SGA) which block D2 dopamine and 5HT2A serotonin receptors have less neurologic and endocrinologic side effects than first generation antipsychotics (typical, conventional). Some SGA with a more complex pharmacodynamic profile reflected by affinity for several receptors (dopaminergic, serotoninergic, histaminergic, muscarinic, $\alpha$ adrenergic) are considered multifunctional drugs (clozapine, olanzapine, quetiapine) in comparison with others such as aripiprazole, risperidone, and paliperidone. Data from epidemiologic studies show that clinicians prefer antipsychotics acting on multiple receptors [14]. This may be explained by the biochemical complexity of schizophrenia or by the fact that intramolecular polypharmacy is a better solution to drug combinations [10]. The pharmacokinetics of antipsychotics is influenced by smoking, excessive water drinking, drug interactions, and body weight. Tobacco lowers the plasma levels of clozapine, olanzapine, and quetiapine but does not influence those of risperidone, paliperidone (9hydroxy-risperidone) and aripiprazole.

The benefits of long acting injectable (LAI) antipsychotics over their oral formulations are the lower and less fluctuating serum concentrations [12] and the administration rhythm: once, twice or every third month [6].

The aim of the present study is to identify factors that may predict the choice of antipsychotic, the prescribed dose and the augmentation strategy.

\section{Materials and Methods}

This cross-sectional two centre based study (Timișoara and Cluj-Napoca, Romania) included outpatients treated with long acting injectable (LAI) new generation antipsychotics.

Study population

All participants in the study have signed an informed consent. The inclusion criteria were: (1) diagnosis of schizophrenia or schizo-affective disorders according to ICD-10; (2) current state - outpatients; (3) at least 3 months of treatment with one of the following LAI antipsychotics: aripiprazole, olanzapine, paliperidone or risperidone; (4) age over 18. The exclusion criteria were: (1) oral treatment with antipsychotics; (2) pregnancy or breastfeeding; (3) current state - inpatients; (4) severe medical co-morbidities accompanied by hepatic or renal impairment; (5) confirmed diagnosis of substance use. The study was carried out according to the Helsinki Declaration Guidelines. The protocol of the study and the patients' informed consent form were approved by the Scientific Research Ethics Committee of "Victor Babeș" University of Medicine and Pharmacy of Timișoara, Romania.

The LAI formulations were chosen to assure treatment adherence. Antipsychotic dose regimens are presented in Table I.

Table I

Antipsychotic dose regimens

\begin{tabular}{|l|l|c|c|}
\hline \multicolumn{1}{|c|}{ LAI antipsychotic } & \multicolumn{1}{|c|}{ Dose $(\mathrm{mg} / \mathrm{months})$} & Number of patients $(\mathrm{N})$ & Percentage (\%) \\
\hline Aripiprazole & 1 injection of $400 \mathrm{mg} / \mathrm{month}$ & 25 & 22.5 \\
\hline \multirow{3}{*}{ Olanzapine } & 1 injection of $300 \mathrm{mg} / \mathrm{month}$ & 6 & 5.4 \\
& 1 injection of $405 \mathrm{mg} / \mathrm{month}$ & 21 & 6.3 \\
& 2 injections of $300 \mathrm{mg} / \mathrm{month}$ & 14 & 18.9 \\
\hline \multirow{2}{*}{ Risperidone } & 2 injections of $37.5 \mathrm{mg} / \mathrm{month}$ & 17 & 12.6 \\
& 2 injections of $50 \mathrm{mg} / \mathrm{month}$ & 6 & 15.3 \\
\hline \multirow{2}{*}{ Paliperidone } & 1 injection of $100 \mathrm{mg} / \mathrm{month}$ & 15 & 5.4 \\
& 1 injection of $150 \mathrm{mg} / \mathrm{month}$ & & 13.5 \\
\hline
\end{tabular}

The subjects were included in three groups (Table II) according to dosage equivalence: low dosage group (LDG) or group I, middle dosage group (MDG) or group II, and high dosage group (HDG) or group III. Apart from the socio-demographic factors (sex, age at study entry), we analysed clinical issues that may influence the choice of the antipsychotic, the prescribed dose and the need for an adjunctive treatment, described below.

Poor prognosis factors (age at disorder onset, total duration of psychosis, and pre-LAI treatment duration). The total duration of the psychosis (DP) is defined as the period (measured in months) from the disorder onset to the present assessment. It is the sum between
LAI treatment duration in months and the pre-LAI period. The latter is defined as the time from the onset of the psychiatric condition to the initiation of LAI treatment.

Severity of psychiatric symptoms measured with Brief Psychiatric Rating Scale - Expanded version 4.0 (BRPS-E) [11]. With its 24 items, BPRS-E has been proved to be more useful in assessing schizophrenic and affective symptoms $[4,21]$ than its previous 16 items BPRS [17], either in acute phase or in remission. Pharmacokinetics: tobacco use, number of cigarettes smoked per day, weight (body mass index and abdominal circumference). 
The three groups according to dose equivalences

\begin{tabular}{|c|l|c|c|}
\hline \multicolumn{1}{|c|}{ Samples } & \multicolumn{1}{|c|}{ Type and dose of antipsychotic } & Number of patients (N) & Percentage (\%) \\
\hline \multirow{3}{*}{ Low dose group (LDG) } & Aripiprazole 1 injection of 400 mg /month & 25 & 22.5 \\
& Olanzapine 1 injection of 300 mg/month & 6 & 5.4 \\
\cline { 2 - 4 } & Total & 31 & 27.9 \\
\hline \multirow{5}{*}{ Moderate dose group (MDG) } & Olanzapine 1 injection of 405 mg/month & 7 & 6.3 \\
& Paliperidone 1 injection of $100 \mathrm{mg} / \mathrm{month}$ & 6 & 5.4 \\
& Risperidone 2 injections of 37.5 mg/month & 14 & 24.3 \\
\cline { 2 - 4 } & Total & 27 & 18.9 \\
\hline \multirow{5}{*}{ High dose group (HDG) } & Olanzapine 2 injections of 300 mg/month & 21 & 13.5 \\
& Paliperidone 1 injection of $150 \mathrm{mg} / \mathrm{month}$ & 15 & 15.3 \\
\hline & Risperidone 2 injections of 50 mg/month & 17 & 47.7 \\
\cline { 2 - 4 } & Total & 53 & \\
\hline
\end{tabular}

\section{Data analysis}

Statistical analysis was performed using IBM SPSS Statistics for Windows (version 20). Because the Shapiro-Wilk test showed a non-Gaussian distribution of the data, in order to compare groups, non-parametric tests were used (the Kruskal-Wallis test, followed by Dunn's post-hoc test, both corrected with the Bonferonni procedure). Potential associations between scores were checked using Spearman's correlation coefficients. The $\chi^{2}$ test was used to analyse differences between categorical variables. Statistical significance was set at 0.05 , and all the results were two-tailed.

\section{Results and Discussion}

Factors predicting the choice of the antipsychotic LAI antipsychotics were developed to improve treatment adherence in schizophrenia. Additional clinical trials proved their efficacy in preventing psychotic and manic symptoms in schizo-affective disorder and bipolar disorder [18].

When analysing the sample according to the antipsychotic type (Table III) the four groups were homogenous in respect to sex, age, disorder onset age, number of smokers, number of cigarettes smoked per day, total duration of psychosis and pre-LAI treatment duration. Significant differences were found concerning BPRS-E scores and LAI duration treatment (as revealed in Table III, by the results of the KruskalWallis test). To see between which groups the differences were significant, we applied the Dunn-Bonferonni post-hoc test. Patients treated with risperidone had significantly shorter duration of LAI treatment than those on paliperidone $(\mathrm{p}<0.0001)$ and aripiprazole $(\mathrm{p}=0.04)$. Probably this finding reflects the situation in which the chance of being maintained on a certain drug is higher if its side effects profile is safer. Both paliperidone (the metabolite of risperidone) and aripiprazole have fewer side effects compared to risperidone.

Subjects on aripiprazole had lower BPRS-E scores than those on paliperidone $(\mathrm{p}=0.01)$. In this case two possibilities may be considered: either aripiprazole was considered more effective than paliperidone, or aripiprazole was prescribed by physicians in less severe patients.

Table III

Sample characteristics according to antipsychotic group

\begin{tabular}{|c|c|c|c|c|c|c|}
\hline & $\begin{array}{c}\text { Risperidone } \\
(\mathrm{N}=31 \\
27.9 \%)\end{array}$ & $\begin{array}{c}\text { Olanzapine } \\
(\mathrm{N}=34 \\
30.6 \%)\end{array}$ & $\begin{array}{c}\text { Aripiprazole } \\
(\mathrm{N}=25, \\
22.5 \%)\end{array}$ & $\begin{array}{l}\text { Paliperidone } \\
(\mathrm{N}=21 \\
18.9 \%)\end{array}$ & $\begin{array}{c}\text { Entire sample } \\
(\mathrm{N}=111 \\
100 \%)\end{array}$ & $\begin{array}{c}\text { Sample comparison } \\
\left(\chi^{2} \text { or Kruskal-Wallis } \mathrm{H}\right)\end{array}$ \\
\hline \begin{tabular}{|l} 
Sex \\
$\quad$ - Men \\
- Women
\end{tabular} & $\begin{array}{l}19(61.3 \%) \\
12(28.7 \%)\end{array}$ & $\begin{array}{l}17(50 \%) \\
17(50 \%)\end{array}$ & $\begin{array}{l}12(48 \%) \\
13(52 \%)\end{array}$ & $\begin{array}{c}16(76.2 \%) \\
5(23.8 \%)\end{array}$ & $\begin{array}{l}64(57.7 \%) \\
47(42.3 \%)\end{array}$ & $\chi^{2}=4.89, p=0.18$ \\
\hline \begin{tabular}{|c|} 
Diagnosis \\
- SCZ \\
- SAD \\
\end{tabular} & $\begin{array}{c}25(80.6 \%) \\
6(19.4 \%)\end{array}$ & $\begin{array}{l}24(70.6 \%) \\
10(29.4 \%)\end{array}$ & $\begin{array}{c}23(92 \%) \\
2(8 \%)\end{array}$ & $\begin{array}{c}14(66.7 \%) \\
7(33.3 \%)\end{array}$ & $\begin{array}{l}86(77.5 \%) \\
25(22.5 \%)\end{array}$ & $\chi^{2}=5.53, p=0.14$ \\
\hline \begin{tabular}{|l} 
Mood stabilizers \\
- Yes \\
- No \\
\end{tabular} & $\begin{array}{l}20(64.5 \%) \\
11(35.5 \%)\end{array}$ & $\begin{array}{c}25(73.5 \%) \\
9(26.5 \%)\end{array}$ & $\begin{array}{l}10(40 \%) \\
15(60 \%)\end{array}$ & $\begin{array}{c}14(66.7 \%) \\
7(33.3 \%)\end{array}$ & $\begin{array}{l}69(62.2 \%) \\
42(37.8 \%)\end{array}$ & $\chi^{2}=7.34, p=0.06$ \\
\hline $\begin{array}{c}\text { Smoking } \\
\text { - Yes } \\
\text { - No } \\
\end{array}$ & $\begin{array}{l}14(45.2 \%) \\
17(54.8 \%)\end{array}$ & $\begin{array}{l}13(38.2 \%) \\
21(61.8 \%)\end{array}$ & $\begin{array}{c}7(28 \%) \\
18(72 \%)\end{array}$ & $\begin{array}{l}11(52.4 \%) \\
10(47.6 \%)\end{array}$ & $\begin{array}{l}45(40.5 \%) \\
66(59.5 \%)\end{array}$ & $\chi^{2}=3.2, p=0.36$ \\
\hline No cigarettes/day & $\begin{array}{c}10.48 \\
(\mathrm{SD}=14.68)\end{array}$ & $\begin{array}{c}7.94 \\
(\mathrm{SD}=11.55)\end{array}$ & $\begin{array}{c}4.88 \\
(\mathrm{SD}=8.28)\end{array}$ & $\begin{array}{c}11.95 \\
(\mathrm{SD}=12.81)\end{array}$ & $\begin{array}{c}8.72 \\
(\mathrm{SD}=12.3)\end{array}$ & $\mathrm{H}=4.18, \mathrm{p}=0.24$ \\
\hline \begin{tabular}{|l|}
$\begin{array}{l}\text { Present age } \\
\text { (years) }\end{array}$ \\
\end{tabular} & $\begin{array}{c}43.77 \\
(\mathrm{SD}=11.08) \\
\end{array}$ & $\begin{array}{c}39.11 \\
(\mathrm{SD}=10.39) \\
\end{array}$ & $\begin{array}{c}43.32 \\
(\mathrm{SD}=12.47)\end{array}$ & $\begin{array}{c}41.76 \\
(\mathrm{SD}=14.04) \\
\end{array}$ & $\begin{array}{c}41.86 \\
(\mathrm{SD}=11.81) \\
\end{array}$ & $\mathrm{H}=3.01, \mathrm{p}=0.39$ \\
\hline
\end{tabular}


FARMACIA, 2020, Vol. 68, 1

\begin{tabular}{|c|c|c|c|c|c|c|}
\hline & $\begin{array}{c}\text { Risperidone } \\
(\mathrm{N}=31 \\
27.9 \%)\end{array}$ & $\begin{array}{c}\text { Olanzapine } \\
(\mathrm{N}=34 \\
30.6 \%)\end{array}$ & $\begin{array}{c}\text { Aripiprazole } \\
(\mathrm{N}=25, \\
22.5 \%)\end{array}$ & $\begin{array}{c}\text { Paliperidone } \\
(\mathrm{N}=21, \\
18.9 \%)\end{array}$ & $\begin{array}{c}\text { Entire sample } \\
(\mathrm{N}=111 \\
100 \%) \\
\end{array}$ & $\begin{array}{c}\text { Sample comparison } \\
\left(\chi^{2} \text { or Kruskal-Wallis } \mathrm{H}\right)\end{array}$ \\
\hline $\begin{array}{l}\text { Age at disorder } \\
\text { onset (years) }\end{array}$ & $\begin{array}{c}29.74 \\
(\mathrm{SD}=11.53) \\
\end{array}$ & $\begin{array}{c}28.58 \\
(\mathrm{SD}=8.91)\end{array}$ & $\begin{array}{c}31.6 \\
(\mathrm{SD}=11.03)\end{array}$ & $\begin{array}{c}28.19 \\
(\mathrm{SD}=8.66)\end{array}$ & $\begin{array}{c}29.51 \\
(\mathrm{SD}=10)\end{array}$ & $\mathrm{H}=1.52, \mathrm{p}=0.68$ \\
\hline $\begin{array}{l}\text { pre-LAI treatment } \\
\text { duration (months) }\end{array}$ & $\begin{array}{c}143.38 \\
(\mathrm{SD}=131.86)\end{array}$ & $\begin{array}{c}115.47 \\
(\mathrm{SD}=117.71)\end{array}$ & $\begin{array}{c}134.28 \\
(\mathrm{SD}=157.18)\end{array}$ & $\begin{array}{c}160.04 \\
(\mathrm{SD}=135.97)\end{array}$ & $\begin{array}{c}135.94 \\
(\mathrm{SD}=133.81)\end{array}$ & $\mathrm{H}=2.28, \mathrm{p}=0.51$ \\
\hline \begin{tabular}{|l|} 
LAI treatment \\
duration (months)
\end{tabular} & $\begin{array}{c}26.29 \\
(\mathrm{SD}=20.92) \\
\end{array}$ & $\begin{array}{c}11.47 \\
(\mathrm{SD}=9.40)\end{array}$ & $\begin{array}{c}11.40 \\
(\mathrm{SD}=8.31)\end{array}$ & $\begin{array}{c}6 \\
(\mathrm{SD}=3.28)\end{array}$ & $\begin{array}{c}14.56 \\
(\mathrm{SD}=14.92) \\
\end{array}$ & $\mathrm{H}=25.14, \mathbf{p}<0.0001 * *$ \\
\hline $\begin{array}{l}\text { Total duration of } \\
\text { the disorder } \\
\text { (months) }\end{array}$ & $\begin{array}{c}169.67 \\
(\mathrm{SD}=138.4)\end{array}$ & $\begin{array}{c}126.94 \\
(\mathrm{SD}=118.64)\end{array}$ & $\begin{array}{c}145.68 \\
(\mathrm{SD}=159.03)\end{array}$ & $\begin{array}{c}166.04 \\
(\mathrm{SD}=135.08)\end{array}$ & $\begin{array}{c}150.49 \\
(\mathrm{SD}=136.42)\end{array}$ & $\mathrm{H}=3.12, \mathrm{p}$ \\
\hline $\begin{array}{l}\text { BPRS-E total } \\
\text { score }\end{array}$ & $\begin{array}{c}37.90 \\
(\mathrm{SD}=11.39) \\
\end{array}$ & $\begin{array}{c}40.79 \\
(\mathrm{SD}=11.75)\end{array}$ & $\begin{array}{c}36.36 \\
(\mathrm{SD}=13.78) \\
\end{array}$ & $\begin{array}{c}46.28 \\
(\mathrm{SD}=14.03) \\
\end{array}$ & $\begin{array}{c}40.02 \\
(\mathrm{SD}=12.89) \\
\end{array}$ & $\mathrm{H}=10.85, \mathbf{p}=\mathbf{0 . 0 1} *$ \\
\hline BMI $\left(\mathrm{kg} / \mathrm{m}^{2}\right)$ & $\begin{array}{c}29.23 \\
(\mathrm{SD}=5.24)\end{array}$ & $\begin{array}{c}27.70 \\
(\mathrm{SD}=5.48)\end{array}$ & $\begin{array}{c}28.30 \\
(\mathrm{SD}=8.61)\end{array}$ & $\begin{array}{c}29.49 \\
(\mathrm{SD}=6.14)\end{array}$ & $\begin{array}{c}28.61 \\
(\mathrm{SD}=6.33)\end{array}$ & $\mathrm{H}=2.65, \mathrm{p}=0.44$ \\
\hline $\mathrm{AC}(\mathrm{cm})$ & $\begin{array}{c}99.87 \\
(\mathrm{SD}=14.03)\end{array}$ & $\begin{array}{c}92.97 \\
(\mathrm{SD}=13.92)\end{array}$ & $\begin{array}{c}95.44 \\
(\mathrm{SD}=20.45)\end{array}$ & $\begin{array}{c}99.27 \\
(\mathrm{SD}=17.88)\end{array}$ & $\begin{array}{c}96.65 \\
(\mathrm{SD}=16.43)\end{array}$ & $\mathrm{H}=3.88, \mathrm{p}=0.27$ \\
\hline
\end{tabular}

${ }^{*} \mathrm{p}<0.05 ; * * \mathrm{p}<0.0001 ; \mathrm{SCZ}=$ schizophrenia; SAD = schizo-affective disorder; $\mathrm{BMI}=$ body mass index; AC $=$ abdominal circumference

\section{Factors predicting the prescribed dose}

When looking to the prescribed dose of the antipsychotics, we found significant differences between the low dosage group (LDG)/group I, the middle dosage group (MDG)/group II and the higher dosage group (HDG)/group III. Patients in the LDG had lower BPRS-E scores than those in MDG $(p=0.04)$ and HDG $(\mathrm{p}=0.02)$, while no differences were found between MDG and HDG, regardless of the antipsychotic. This is illustrated in Figure 1, where the box plot (left) compares the medians and data spread across groups, while the diagram (right) shows significant differences between the mean ranks of the three compared groups.

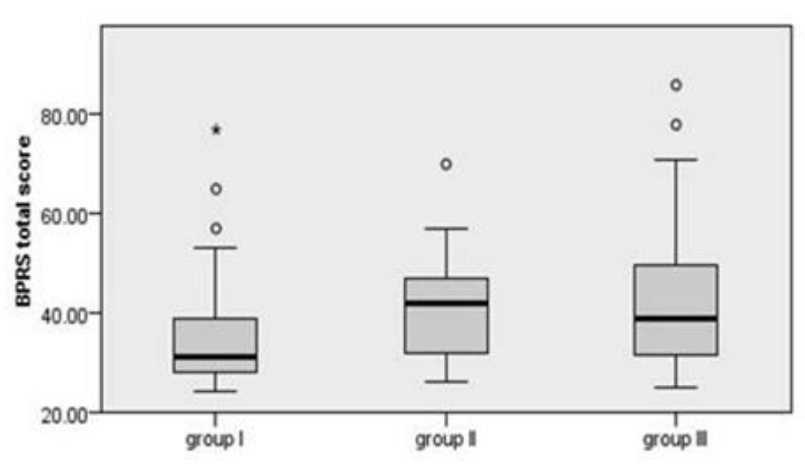

Figure 1.

Independent sample Kruskal-Wallis test results and pair wise comparison between the three groups (Dunn-Bonferonni test)
This means that outpatients with less severe residual symptoms are candidates for a fixed dose of aripiprazole $400 \mathrm{mg} / \mathrm{month}$, or a lower dose of olanzapine $(300$ $\mathrm{mg} / \mathrm{month}$ ). Aripiprazole is known to have the safest side effects profile amongst the four LAI antipsychotics in children [1], as well as in adults [15, 19, 22]. LDG patients had higher total BPRS-E scores than subjects in the MDG, but the result was not statistically significant. In addition, the three dosage groups were homogenous as regards socio-demographic and different clinical data. Regarding the low prognosis factors (age at disorder onset, pre-LAI treatment duration, and total duration of psychosis), all three dosage groups were homogenous. Another interfering factor is represented by smoking, which affects the patients treated with olanzapine. Being a cytochrome P450 1A2 inducer, tobacco decreases the plasma levels of olanzapine [2, 7]. Again, as it is shown in Table IV, there are no differences between the three dosages groups regarding tobacco use or the number of 
FARMACIA, 2020, Vol. 68, 1

cigarettes smoked per day. A further issue is the body weight. In our study, we found no significant differences between the three dosages groups concerning the patients' weight expressed by body mass index (BMI) or by abdominal circumference. This is in accordance with research data showing that there is no clear relationship between antipsychotic dose and the medication induced weight gain $[16,20]$. An international systematic survey conducted on a sample of clinical and research experts showed that the recommended antipsychotic doses were lower in underweight patients (according to BMI), but significantly unaffected in overweight subjects [5]. As subjects in the HDG do not differ significantly from patients in the MDG concerning objective data such as age, sex, smoking habits, BMI, abdominal circumference and the above mentioned low prognostic factors, there may be subjective factors such as personal experience persuading clinicians to maintain these patients on the highest doses.

Table IV

Sample characteristics according to dosage groups

\begin{tabular}{|c|c|c|c|c|}
\hline & $\begin{array}{l}\text { Group 1: LDG } \\
(\mathrm{N}=31)\end{array}$ & $\begin{array}{c}\text { Grup II: MDG } \\
(\mathrm{N}=27)\end{array}$ & $\begin{array}{l}\text { Grup III: HDG } \\
(\mathrm{N}=53)\end{array}$ & $\begin{array}{c}\text { Sample comparison } \\
\left(\chi^{2} \text { or Kruskal-Wallis } \mathrm{H}\right)\end{array}$ \\
\hline $\begin{array}{l}\text { Sex } \\
\quad \text { - Men } \\
\quad \text { - Women }\end{array}$ & $\begin{array}{l}17(54.8 \%) \\
14(45.2 \%)\end{array}$ & $\begin{array}{l}15(55.6 \%) \\
12(44.4 \%)\end{array}$ & $\begin{array}{l}32(60.4 \%) \\
21(39.6 \%)\end{array}$ & $\chi^{2}=0.31, p=0.85$ \\
\hline $\begin{array}{r}\text { Diagnosis } \\
-\mathrm{SCZ} \\
-\mathrm{SAD} \\
\end{array}$ & $\begin{array}{c}28(90.3 \%) \\
3(9.7 \%)\end{array}$ & $\begin{array}{c}21(77.8 \%) \\
6(22.2 \%)\end{array}$ & $\begin{array}{l}37(69.8 \%) \\
16(30.2 \%)\end{array}$ & $\chi^{2}=4.71, p=0.09$ \\
\hline $\begin{array}{l}\text { Mood stabilizers } \\
\text { - Yes } \\
\text { - No }\end{array}$ & $\begin{array}{l}14(45.2 \%) \\
17(54.8 \%)\end{array}$ & $\begin{array}{l}14(51.9 \%) \\
13(48.2 \%)\end{array}$ & $\begin{array}{l}41(77.4 \%) \\
12(22.6 \%)\end{array}$ & $\chi^{2}=10.23, \mathbf{p}=\mathbf{0 . 0 0 6} * *$ \\
\hline $\begin{array}{c}\text { Smoking } \\
- \text { Yes } \\
\text { - No }\end{array}$ & $\begin{array}{l}10(32.3 \%) \\
21(67.7 \%)\end{array}$ & $\begin{array}{l}9(33.3 \%) \\
18(66.7 \%)\end{array}$ & $\begin{array}{l}26(49.1 \%) \\
27(50.9 \%)\end{array}$ & $\chi^{2}=3.05, p=0.22$ \\
\hline No. cigarettes/day & $5.87(\mathrm{SD}=8.89)$ & $6.29(\mathrm{SD}=10.88)$ & $11.62(\mathrm{SD}=14)$ & $\mathrm{H}=4.73, \mathrm{p}=0.09$ \\
\hline Present age (years) & $41.61(\mathrm{SD}=12.1)$ & $43.14(\mathrm{SD}=10.99)$ & $41.35(\mathrm{SD}=12.21)$ & $\mathrm{H}=0.48, \mathrm{p}=0.78$ \\
\hline $\begin{array}{l}\text { Age at disorder onset } \\
\text { (years) }\end{array}$ & $29.48(\mathrm{SD}=10.96)$ & $30(\mathrm{SD}=10.17)$ & $29.28(\mathrm{SD}=9.72)$ & $\mathrm{H}=0.15, \mathrm{p}=0.93$ \\
\hline $\begin{array}{l}\text { pre-LAI treatment } \\
\text { duration (months) }\end{array}$ & $136.96(\mathrm{SD}=146.77)$ & $146(\mathrm{SD}=139.44)$ & $130.21(\mathrm{SD}=125.06)$ & $\mathrm{H}=0.36, \mathrm{p}=0.83$ \\
\hline $\begin{array}{l}\text { LAI treatment duration } \\
\text { (months) }\end{array}$ & $12.64(\mathrm{SD}=9.78)$ & $15.03(\mathrm{SD}=15.95)$ & $15.43(\mathrm{SD}=16.89)$ & $\mathrm{H}=0.17, \mathrm{p}=0.92$ \\
\hline $\begin{array}{l}\text { Total duration of the } \\
\text { disorder (months) }\end{array}$ & $149.61(\mathrm{SD}=147.91)$ & $161.03(\mathrm{SD}=143.66)$ & $145.64(\mathrm{SD}=127.84)$ & $\mathrm{H}=0.45, \mathrm{p}=0.79$ \\
\hline BPRS-E total score & $36.19(\mathrm{SD}=12.74)$ & $40.81(\mathrm{SD}=10.59)$ & $41.86(\mathrm{SD}=13.75)$ & $\mathrm{H}=6.41, \mathbf{p}=\mathbf{0 . 0 4} *$ \\
\hline BMI $\left(\mathrm{kg} / \mathrm{m}^{2}\right)$ & $28.31(\mathrm{SD}=8.21)$ & $28.21(\mathrm{SD}=4.10)$ & $28.97(\mathrm{SD}=6.11)$ & $\mathrm{H}=1.05, \mathrm{p}=0.59$ \\
\hline $\mathrm{AC}(\mathrm{cm})$ & $95.16(\mathrm{SD}=19.81)$ & $96.41(\mathrm{SD}=13.59)$ & $97.64(\mathrm{SD}=15.81)$ & $\mathrm{H}=1.40, \mathrm{p}=0.49$ \\
\hline
\end{tabular}

Factors predicting augmentation strategy with adjuvant mood stabilizers

As LAI antipsychotics appeared to be less effective in preventing depressive symptoms than manic and psychotic ones [18], the treatment in schizo-affective disorder requires the use of mood stabilizers. In our sample, only $25(22.5 \%)$ patients were diagnosed with schizo-affective disorder requiring the use of a mood stabilizer to prevent mood changes. Yet, 69 (62.2\%) subjects of the entire sample received an additional mood stabilizer, regardless of the type of the antipsychotic (Table III). Adjunctive treatment with a mood stabilizer was found more frequently in patients with higher BPRS-E scores $(\mathrm{U}=1806.5, \mathrm{p}=0.03)$, regardless of the antipsychotic type. Furthermore, mood stabilizers were used more frequently in HDG subjects, when compared with MDG and LDG patients $\left(\chi^{2}=10.23, \mathrm{p}=0.006\right)$ as shown in Table IV and Figure 2. In this respect, we may infer that in patients with a poor remission (higher BPRS-E scores or higher antipsychotic dose regimens), the mood stabilizers were used as an augmentation strategy. No significant differences were found between MDG and LDG concerning the augmentation with a mood stabilizer. In patients with schizophrenia, augmentation is realized using mood stabilizers or antidepressants. Among them, mood stabilizers with antiepileptic action such as valproate and carbamazepine are known to induce liver dysfunction, leukocytopenia, thrombocytopenia, obesity, dyslipidaemia and diabetes mellitus in various degrees among individual agents [3]. Nevertheless, the treatment with mood stabilizers adds the benefit of reducing the risk of suicide [8]. 


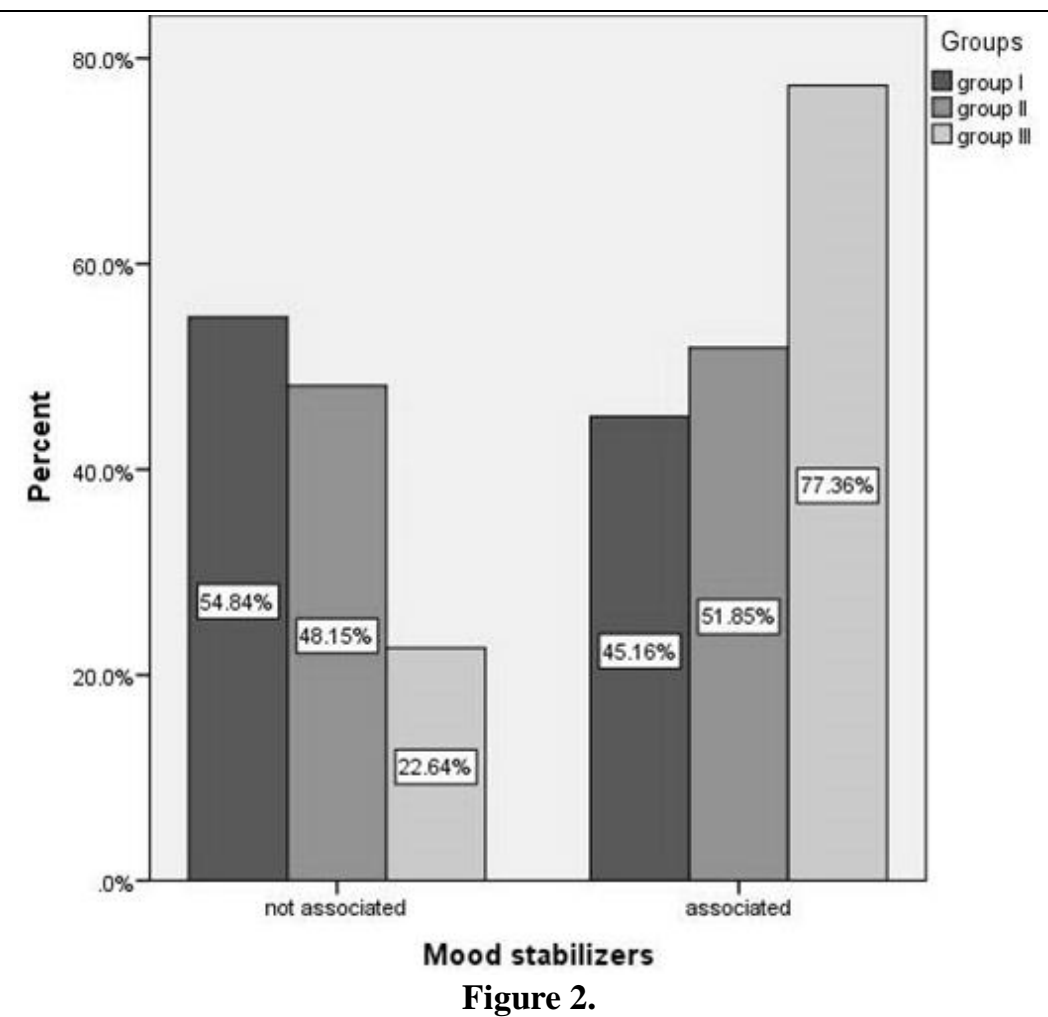

Differences between groups regarding the associated mood stabilizer medication

\section{Conclusions}

Clinical factors influencing antipsychotic's choice were symptomatology, possible antipsychotic side effects and dosage. Patients presenting mild symptoms were more frequently candidates for antipsychotics with a lower profile of side effects, such as aripiprazole, or lower doses of antipsychotics. Treatment resistance, reflected by residual symptoms, required higher antipsychotic doses and/or adding of an adjunctive mood stabilizer.

The ascertained adherence to treatment and the fairly constant antipsychotic plasma levels ensured by the LAI formulations constitute the study's strengths. As a limitation, we acknowledge that the rather small size of our study group decreases the statistical power.

\section{Conflict of interest}

The authors declare no conflict of interest.

\section{References}

1. Andreescu N, Nussbaum LA, Hogea LM, Grădinaru RA, Muntean C, Ştefãnescu R, Puiu M, Antipsychotic treatment emergent adverse events in correlation with the pharmacogenetic testing and drug interactions in children and adolescents with schizophrenia and bipolar disorder. Farmacia, 2016; 64(5): 736-744.

2. Carrillo JA, Herráiz AG, Ramos SI, Gervasini G, Vizcaíno S, Benítez J, Role of the smoking-induced cytochrome P450 (CYP) 1A2 and polymorphic CYP2D6 in steady-state concentration of olanzapine. J Clin Psychopharmacol., 2003; 23(2): 119-127.
3. Correll CU, Detraux J, De Lepeleire J, De Hert M, Effects of antipsychotics, antidepressants and mood stabilizers on risk for physical diseases in people with schizophrenia, depression and bipolar disorder. World Psychiatry, 2015; 14(2): 119-136.

4. Dehelean L, Andor M, Romosan AM, Manea MM, Romosan RS, Papava I, Bredicean AC, Buda VO, Tomescu MC, Pharmacological and disorder associated cardiovascular changes in patients with psychosis. A comparison between olazapine and risperidone. Farmacia. 2018; 66(1):129-134.

5. Gardner DM, Murphy AL, O'Donnell H, Centorrino F, Baldessarini RJ, International consensus study of antipsychotic dosing. Am J Psychiatry, 2010; 167(6): 686-693.

6. Gareri P, Segura-García C, Manfredi VG, Bruni A, Ciambrone P, Cerminara G, De Sarro G, De Fazio P, Use of atypical antipsychotics in the elderly: a clinical review. Clin Interv Aging, 2014; 9: 13631373.

7. Gex-Fabry M, Balant-Gorgia AE, Balant LP, Therapeutic drug monitoring of olanzapine: the combined effect of age, gender, smoking, and comedication. Ther Drug Monit., 2003; 25(1): 46-53.

8. Gibbons RD, Hur K, Brown CH, Mann JJ, Relationship between antiepileptic drugs and suicide attempts in patients with bipolar disorder. Arch Gen Psychiatry, 2009; 66: 1354-1360.

9. Gilmer TP, Dolder CR, Lacro JP, Folsom DP, Lindamer L, Garcia P, Jeste DV, Adherence to treatment with antipsychotic medication and health care costs among Medicaid beneficiaries with schizophrenia. Am J Psychiatry, 2004; 161(4): 692-699.

10. Handra C, Coman OA, Coman L, Enache T, Stoleru S, Sorescu AM, Ghiță I, Fulga I, The 
connection between different neurotransmitters involved in cognitive processes. Farmacia, 2019; 67(2): 193-201.

11. Lukoff D, Nuechterlein KH, Ventura J, Manual for the Expanded BPRS. Schizophr Bull., 1986; 12: 584-602.

12. Mannaert E, Vermeulen A, Remmerie B, Bouhours P, Levron JC, Pharmacokinetic profile of long-acting injectable risperidone at steady-state: comparison with oral administration. L'Encéphale, 2005; 31(5): 609-615.

13. Marshall M, Lewis S, Lockwood A, Drake R, Jones $\mathrm{P}$, Croudace $\mathrm{T}$, Association between duration of untreated psychosis and outcome in cohorts of firstepisode patients: a systematic review. Arch Gen Psychiatry, 2005; 62(9): 975-983.

14. Nasrallah HA, Atypical antipsychotic-induced metabolic side effects: insights from receptor-binding profiles. Nature, 2008; 13: 27-35.

15. Nasrallah HA, Aquila R, Du Y, Stanford AD, Claxton A, Weiden PJ, Long-term safety and tolerability of aripiprazole lauroxil in patients with schizophrenia. CNS Spectrums, 2018: 1-9.

16. Newcomer JW, Second-generation (atypical) antipsychotics and metabolic effects. CNS Drugs, 2005; 19(1): 1-93.

17. Overall JE, Gorham DR, The Brief Psychiatric Rating Scale. Psychol Rep., 1962; 10: 790-812.
18. Pacchiarotti I, Tiihonen J, Kotzalidis GD, Verdolini N, Murru A, Goikolea JM, Valentí M, Aedo A, Vieta E, Long-acting injectable antipsychotics (LAIs) for maintenance treatment of bipolar and schizoaffective disorders: A systematic review. Eur Neuropsychopharmacol., 2019; 29(4): 457-470.

19. Ribeiro EL, de Mendonça Lima T, Vieira ME, Storpirtis S, Aguiar PM, Efficacy and safety of aripiprazole for the treatment of schizophrenia: An overview of systematic reviews. Eur J Clin Pharmacol., 2018; 74(10): 1215-1233.

20. Simon V, van Winkel R, De Hert M, Are weight gain and metabolic side effects of Atypical Antipsychotics Dose Dependent? A Literature Review. J Clin Psychiatry, 2009; 70(7): 1041-1050.

21. Velligan D, Prihoda T, Dennehy E, Biggs M, ShoresWilson K, Crismon ML, Rush AJ, Miller A, Suppes T, Trivedi M, Kashner TM, Brief psychiatric rating scale expanded version: How do new items affect factor structure?. Psychiatry Res., 2005; 135(3): 217-228.

22. Weiden PJ, Claxton A, Du Y, Lauriello J, 63 Longterm Outcomes with Aripiprazole Lauroxil for the Treatment of Schizophrenia: A 2-Year, Phase 3, Multicenter Extension Study. CNS Spectrums, 2019; 24(1): 208-209. 